\title{
Re-orientalism in Shauna Singh Baldwin's The Selector of Souls
}

\author{
Urvashi Kaushal \\ Sardar Vallabhbhai National Institute of Technology, Surat \\ E-mail: urvashikaushal6@gmail.com, Orcid Id.oooo-ooo2-6774-6849
}

\begin{abstract}
In his seminal work Orientalism Edward Said destabilized the Euro-American practice of constructing, approving and disseminating a stereotypical image of Asia as exotic backward called the 'Orient'. This paper takes Said's concept of Orientalism as a premise to highlight 'self-orientalism' or 're-Orientalism' as a growing trend in South Asian diaspora writers, especially since the turn of the 21st century. It utilizes the idea of orientalism and reads Shauna Singh Baldwin's The Selector of Souls against the grain to accentuate the reification of Indian culture into a commodity and homogenisation of complex cultural differences in multicultural India for the consumption of the West. In its effort to find answers for this growing trend, it analyses the nexus between location and commodification of literature produced by diaspora writers.
\end{abstract}

Keywords: orientalism, re-orientalism, new-orientalism, neo-orientalism, diaspora writers, commodification.

\section{Introduction}

Edward Said's Orientalism challenged and destabilised the metropolitan academic institution's claim of understanding the cultural products of Asia by consistently deconstructing the stereotypical image of the exotic 'Orient'. Said exposed the underlined power politics behind the discourse by insisting that "Orientalism can be discussed and analysed as the corporate institution of dealing with the Orient- dealing with it by making statements about it, authorising views of it, describing it, by teaching it, settling it, ruling over it; in short, Orientalism as a Western style of dominating restructuring and having the authority over the Orient"(3).His insight on how West constructs the 'Orient' by casting East as the 'Other' provided a new lens to examine the representation of 'Orient' in cultural products. This paper is based on the argument that the "Orientals are perpetrating (new forms of) orientalism," (Lau and Mendes, pp.7) which raises questions of accuracy and authenticity on their representation.

While the postcolonial critics question the 'Occident' for its prejudice in constructing and disseminating literary text of the 'Orient', Arif Dirlik posits "a reconfigured relationship between politics, culture and history" (99) by tracing a new location and structure in the discourse and theorising it as 'Orientalism of the Orientals'. He explains the Asian intellectuals' contribution to the emergence of orientalism as a practice and concept created due to their movement in 'contact zones' significantly dominated by Euro-American intellectuals. His 'self-orientalism' concept directed a new angle of criticism with the argument, "Euro- American images of Asia may have been incorporated into the self images of Asians"(104).

(c) AesthetixMS 2020. This Open Access article is published under a Creative Commons Attribution Non-Commercial 4.o International License (http://creativecommons.org/licenses/by-nc/4.o/), which permits non-commercial re-use, distribution, and reproduction in any medium, provided the original work is properly cited. For citation use the DOI. For commercial re-use, please contact editor@rupkatha.com. 
Spivak fleetingly commented on this strategy of third world literature as 'new Orientalism' (277) triggered by the global success of Midnight's Children. In a significant development, Elleke Boehmer (18) recognised the threats and called this 'new orientalist tendency' as an 'enthusiastic exoticising' of postcolonial literary texts as the sites of creation for the exotic other. She also added the influence of capitalism and commodification while foregrounding the question of homogenising practice through which views of the colonial are often constituted. Whether the nomenclature used is Arif Dirlik's Self-Orientalism, Elleke Boehmer's Neo-orientalism, Anis Shivani's new Orientalism, Timothy Mitchell's reverse orientalism or Lisa Lau's re-Orientalism, this concept encourages reading against the grain to analyse complicity of Orientals in "composing a positive image of the western self while casting the 'East' as its negative alter ego, alluring and exotic, dangerous and mysterious, always the 'Other' "(Lau and Mendes, 2011p.-3). This paper borrows the concept of re-orientalism as expounded by Lau (2009) to argue that it is an emergent practice in the writings of South Asian diaspora writers mainly positioned in the US, Canada and UK to act as the representatives of their homeland. As the gatekeepers of culture they indulge in Orientalising the events, culture and society of the homeland.

Home and identity has long been the locus of diaspora writings. While most diaspora writers have mourned the loss, Salman Rushdie in Imaginary Homelands talks about using memory to recreate home. He argues that diaspora writers who write about their homelands "are capable of writing from a kind of double perspective: because they are at one and the same time insiders and outsiders in this society" (p.75). Shauna Singh Baldwin is an Indo-Canadian writer who enjoys this 'double perspective' as her hyphenated identity empowers her to be the insider as well as an outsider. This essay utilises the idea of re-orientalism to analyse Shauna Singh Baldwin's use of location to represent India "through Western lenses, within western frames of discourse, and via Western knowledge systems" (Lau and Dwivedi, p.5).

The Selector of Souls (2012) is her attempt to trap the essence of multi-ethnic, multireligious and multicultural nation by presenting a comprehensive view of India after 1992. The narrative interweaves a plethora of social, political, religious issues inherently organic in a multilayered and diverse country like India. In alternate chapters it narrates the story of two socially juxtaposed protagonists whose lives intersect and they bond over a mission to save unwanted girls from being killed at birth or made to leading miserable lives. The protagonist Anu's journey reflects her dichotomous struggle with external forces like abusive husband, and the dilemma over her quest for religious identity. The other central character, Damini, is at odds with humanity as she advises pregnant village women for pre-natal selection of their child owing to her belief, "when a woman is two-in-one and must be asked what she wants and if a cleaning is her wish, she should be cleaned" (528). Her supposition "the future will be better if girls are cleaned out" (446) has roots in the past act of abandoning her week-old granddaughter at the threshold of a temple atop the hills of Himalayas. The new born is disowned, "Because it became a girl", along with it came all the expectations and demands of her someday husband and family" (8).

From the very beginning, the novel attempts to foreground through innumerable instances, the subordinate status of women who are referred to as 'paraya dhan,' as the cost to raise and marry off girls causes anxiety to parents. Son preference is an undeviating concern as even "Mothers can reject daughters in many ways, not only by starving, selling, abandoning or exchanging them for sons" (371). Baldwin's attempt to hold a mirror to Indian society becomes problematic due to the multiple incidents interspersed in the narrative, which generalise son preference across religions and social strata. Anu's husband and in-laws are indifferent and insensitive towards her daughter Chetna and eagerly wait for an heir. Kiran, another character, 
grows desperate and is willing to exchange her newborn daughter for a son born to a socially ostracised rape victim. Universally, son becomes the cause of misery but daughters are made to lead a miserable life. Misery and despondency overshadow Chetna's life, who was born out of marital rape, but is happy to be adopted by her Aunt Rano in Canada after she accidently hears her Anu tell her cousin, "I never wanted this child" (44). But her return to India and to Anu once Rano conceives, leads to her complete alienation. Chetna's despondency presents a glimpse of an unwanted child's quest for identity and parental love when she on phone pleads to her Aunt Rano, "if she could please come home" but unfortunately, her journey like her predicament is left inconclusive.

With her diasporic experience Baldwin picks the glitches of Indian ethos, and also expounds the problem for western publishers and readers by homogenising it as an evil prevalent in Indian society. By "recycling and reinforcing the shallowest of stereotypes" (Lau and Mendes, p.5), her narrative sets to validate the title and the need for selection of souls. The comprehensiveness of her representation becomes questionable due to her undeniable effort to re-Orientalise stray incidents by homogenising beliefs and practices of multicultural Indian society.Contentions that Baldwin like other diaspora writers writes with a "double perspective" as argued by Rushdie, holds weak ground as it overlooks the fact that she has created "a version and no more than one version of all the hundreds of millions of possible versions" (Rushdie, 2006, p.75). Even if Rushdie's argument is taken as an excuse for diaspora writers' lack of comprehensiveness, what cannot be denied is, "This ironic enactment subtly converts spectacle into mirror, grotesquery into character flaw and magic into realism for astute reader. (Shivani, pp.3)"

In her narrative women are stereotypically counselled into subordination and selfabnegation with words like, "Your dharma is to be with your husband," or "Women from good 'Hindu' families don't divorce” (55). So deep is the expectation of conformity that Anu's slight transgression from her subordinate position results in her bruised face and swollen eyes, reminding her that, "She should have noticed the thunderous anger gathering behind her husband's eyes" (51). Anu's character condescendingly portrays the predicament of victims of domestic violence and abuse, who pray in their heart, "Lord give him a heart attack. Maim him before I sin" (43). Although subtly, it also challenges the patriarchal order according to which, "Raping your wife is not a crime. Killing your husband is a crime" (46). Her physical, sexual, emotional abuse ends with her patriarchal misgivings when she takes a decisive step by denouncing her marital life and religion. Once again, Baldwin's representation becomes naïve and problematic as it delineates all the female characters entrapped in one or other exploitative relationships. Damini is labelled as 'dayan' responsible for her husband's untimely death and is relentlessly exploited by Suresh, her wastrel son involved in extremist activities. Even other characters like Damini's old Mem- saab is compelled to end her life due to her son's atrocities. Furthermore, Mem-saab's son Amanjit drives his wife Kiran to unimaginable lengths to deliver a son. Hence, the characters are anything more than "derivative caricatures" added to show concern for "a narrowly defined multicultural identity" (Shivani, p.3).

Representation of caste hegemony finds expression through the trials and tribulations of Samuel and Goldina. Their efforts to acquire inclusivity by converting to different religions get repeatedly thwarted by hegemonic forces of society. Although these stray incidents and characters from minority community point out the apertures in the secular and democratic claim of India, nowhere in the voluminous novel does Baldwin nudge this image or present a homogeneous society which is intrinsic to all urban middleclass dwellings commonly found in 
Indian cities. Hence, keeping with the re-Orientalism practice she "colludes in serving up unwholesome picture" of India and "panders to western satiation" (Lau and Dwivedi, 8).

Along with the myriad social evils depicted, the novel also establishes the undercurrents of religious acrimony between different communities, kindled by political outfits. The growing animosity between different religious sects runs parallel to Anu's religious disillusionment. She converts to Christianity and becomes a nun as she wanted "a more egalitarian community" (92). But the church's diktat of "no female should lead the congregation" (469) disillusions her. Her dilemma represents the existential crisis and confusion, similar to the anarchy brought forth in the plot by religious extremism. The incidents of sectarian violence after 1992 Babari Majid demolition leads to the culmination of the plot along with the victimization of women and minority. Through many interspersed incidents the narrative presents, "sectarian violence and intolerance... But it is brown-skinned Indo-Aryan supremacists who figure most prominently in Baldwin's fictional world, along with many of the other warring castes, sects and religions in modern India" (Barber).Hence, she creates a dystopian image by generalizing and homogenizing difference of cultures and beliefs of complex multicultural Indian society.

Interestingly, re-Orientalism also presupposes, the orient continues to be "as unruly, exuberant, mysterious, irregular, rhythmic- as were the snake charmers or black minstrel of another time" (Boehmer, p.19). Under Rushdie's influence, Baldwin incorporates the use of magic realism and divine intervention to render up mysterious East for the consumption of the West. In a bizarre turn of events, the spirit of Lord Gokunath's spirit descends in a local ojha to reprimand humans for "cleaning out girls". With the aim to enlighten the village population, he illustrates, "Without girls, there would be no women, and without women you would not be born, and without women's Shakti, you cannot survive" (447). Divine intervention drives Damini towards becoming the voice of the "Goddess Anamika Devi (Goddess of the unborn)", as "someone had to summon the right energy to bridge the gulf between human and divine" (449). The creation of the mythical Goddess from a pot, whose arms and accessories are designed after much debate, complies with the west's perception of India as a land of mystics and snake charmers.An interesting point to note is that this novel received praise for the "vivid and luminous drawing us into the multitude of cultures and religions, the richly textured worlds of India" (Gulland).

\section{Conclusion}

Baldwin's overtly dystopian representation and homogenization of complex cultural differences for the reification of Indian culture into a commodity, may be a consequence of her own cultural entanglement and hybridity, but it also raises doubts on the accuracy and authenticity of portrayal. A rationale presented in favour of re-Orientalism practiced by diaspora writers' is regarding their location where "the textual traffic is concentrated in and directed from" (Boehmer, p.19)as it provides "greater access to publication, promotion, and wide-spread distribution channels" (Lau, 2005).In varied ways, many critics have warned against "the conglomerate publishing industry" that has been "engaging in the commodification of an exoticised orientalism" (Shivani, p.1).This novel depicts in many ways Baldwin's complicity to the western perceived expectations due to the pressures imposed by the global cultural demand for stereotyped exotically flavoured picture of the East.

Like the other diaspora writers who,"utilize positionality to prove eligibility as representative and validity of testimony and authority" (Lau and Mendes, p.7) Baldwin too, uses her elite position and hyphenated identity to act as the keeper of literary image of India, while she creates and re-creates India, even if, her re-telling lead to a "warped, skewed and distorted portrayal" (Lau, 2005, 242). However, her misrepresentations, limited, partial or distorted 
representations of internal inconsistencies of India are at the unfortunate expense of a more holistic representation of her homeland. Her "metonymic reductionism" (Dirlik, p.11) that led to the portrayal of Indian societies in terms of some backward "culture trait that homogenized differences" within its societies, suppressed a recognition of the diversity operating in India. The novel is a product of her "lack of engagement or, at least, engaging only at the superficial levels" (Lau and Mendes, p.8) because with a privileged position she re-visits India through her writings, but "in tourist guide mode" (Lau and Mendes, p.8).

Unfortunately, the rate at which writings like Baldwin's are produced for the purpose of commodification, consumption and appreciation of the West, they are instrumental in creating cultural alterity of the East, purely out of their imagined and fictionalized diasporic experience. Therefore, their accuracy and authority "needs to be questioned and resisted" (Boehmer, 19) before it becomes more real than reality.

\section{References}

Baldwin, S. S. (2012). The Selector of Souls. Alfred A. Knopf.

Barber, J. (2012) Shauna Singh Baldwin: 'I've been a minority in three different countries'The Globe and Mail. Wednesday, Sep. 26, 2012 5:0oPM EDT. http://www.theglobeandmail.com/arts/books-andmedia/shauna-singh-baldwin-ive-been-a-minority-in-three-different-countries/article4570137. Web 13 April 2017.

Boehmer, E. (2006). Questions of Neo-Orientalism. Interventions: International Journal of Postcolonial Studies, vol. 1(1), pp. 18-21.

Dirlik, A. (1996). Chinese History and the Question of Orientalism. History and Theory , vol. 35(4), pp.96118.

Gulland, S. Advance praise for The Selector of souls. https://www.shaunasinghbaldwin.com/books/theselector-of-souls/. Web 23 July 2020.

Lau, L. (Feb.2005). Making the Difference: The Differing Presentations and Representations of South Asia in the Contemporary Fiction of Home and Diasporic South Asian Women Writers. Modern Asian Studies, vol. 39(1), pp.237-256.

Lau, L. and Mendes, A. C. (2011). Introducing Re-Orientalism: A new manifestation of Orientalism, Re Orientalism and South Asian Identity Politics: The Oriental Other Within. Routledge, pp-1-16.

Lau, L. and Dwivedi, O.P. (2014).Introducing Re-OrientalismTheory and Discourse in Indian writing in English, Re -Orientalism and Indian Writing in English. Palgrave Macmillan, pp.1-26.

Mitchell, T. (1998).Orientalism and the Exhibitionary Order, in Donald Preziosi (ed.) The Art of Art History: A Critical Anthology, Oxford. Oxford University Press.

Mustafa, N.(Sept. 27, 2012). Surrendering Sweetness: In Conversation with Shauna Singh Baldwin. Hazlitt. http://hazlitt.net/feature/surrendering-sweetness-conversation-shauna-singh-baldwin. Web 13 April 2017.

Rushdie, S. (1983). The Indian Writer in England, In the eye of Beholder: Indian Writing in English. Commonwealth Institute, pp 75-83.

Rushdie, S. (2006). Imaginary Homelands, Postcolonial Studies Reader.B. Ashcroft, G. Griffiths and H. Tiffin (Eds). Routledge, pp. 428-434.

Said, E. (1979) Orientalism. New York.Vintage Books.

Spivak, G.C. (1993) Outside in the Teaching Machine, New York: Routledge. 
Shivani, A. (2006). Indo-Anglian fiction: the new Orientalism, Race E Class, 47(4) pp. 1-25.

Dr. Urvashi Kaushal is an Assistant Professor of English in the Applied Mathematics and Humanities Department of National Institute of Technology, Surat, Gujarat. She teaches English and Communication Skills to Engineering and Science students at the Undergraduate and Post Graduate level. Her area of interest is Postcolonial Fiction, Diaspora Literature and Communication Skills. 